\title{
Rhipicephalus sanguineus sensu lato (Ixodidae) in synantropic rodents in Rio Grande do Sul, Brazil
}

\author{
Rhipicephalus sanguineus sensu lato (Ixodidae) em roedores sinantrópicos no Rio Grande do Sul, Brasil \\ Kathleen Tavares Winkel ${ }^{1 *}$; Paulo Bretanha Ribeiro ${ }^{2}$; Lidiane Oliveira Antunes ${ }^{1}$; \\ Marcial Corrêa Cárcamo ${ }^{1}$; Élvia Elena Silveira Vianna ${ }^{2}$ \\ ${ }^{1}$ Laboratório de Biologia de Insetos, Programa de Pós-Graduação em Parasitologia, Departamento de Microbiologia e Parasitologia, \\ Instituto de Biologia, Universidade Federal de Pelotas - UFPEL, Pelotas, RS, Brasil \\ ${ }^{2}$ Laboratório de Biologia de Insetos, Departamento de Microbiologia e Parasitologia, Instituto de Biologia, \\ Universidade Federal de Pelotas - UFPEL, Pelotas, RS, Brasil
}

Received November 18, 2013

Accepted February 6, 2014

\begin{abstract}
Rhipicephalus sanguineus, the brown dog tick, is responsible for maintaining and transmitting various pathogens, both in animals and human beings, and it is of great sanitary importance. This communication reports the first occurrence of Rhipicephalus sanguineus sensu lato parasitizing Rattus norvegicus in the state of Rio Grande do Sul, Brazil, and it is also the first record of this tick species parasitizing Rattus rattus in Brazil. The rodents were captured from the port area, located in the city of Pelotas, Rio Grande do Sul, Brazil. We collected 6 larvae of this tick species from 2 male $R$. rattus individuals, and 3 larvae from 2 female $R$. norvegicus individuals; parasitized specimens of both rodent species were captured from different sites within the experimental area. This record broadens the number of Rhipicephalus sanguineus sensu lato hosts in urban areas, indicating the need for continued monitoring on population density for both $R$. sanguineus and synanthropic rodents.
\end{abstract}

Keywords: Tick, Rhipicephalus sanguineus, Rattus norvegicus, Rattus rattus.

\section{Resumo}

Rhipicephalus sanguineus, carrapato-vermelho-do-cão, é responsável por manter e transmitir diversos patógenos tanto para animais quanto para o homem, sendo de grande importância sanitária. Essa comunicação relata a primeira ocorrência de Rhipicephalus sanguineus sensu lato parasitando Rattus norvegicus no Estado do Rio Grande do Sul e, pela primeira vez, Rattus rattus no Brasil. Os roedores foram capturados na área portuária da cidade de Pelotas, Rio Grande do Sul, Brasil. Foram coletadas seis larvas desse carrapato em dois machos de $R$. rattus e três larvas em duas fêmeas de $R$. norvegicus. As duas espécies de roedores parasitados foram capturadas em pontos distintos na área do experimento. Esse registro amplia o número de hospedeiros de Rhipicephalus sanguineus sensu lato em áreas urbanas, indicando a necessidade de monitoramento contínuo da densidade populacional, tanto de $R$. sanguineus quanto de roedores sinantrópicos.

Palavras-chave: Carrapato, Rhipicephalus sanguineus, Rattus norvegicus, Rattus rattus.

Infestation by Rhipicephalus sanguineus (Latreille, 1806) (Acari, Ixodidae), the brown dog tick, has increased considerably in recent years in southern Rio Grande do Sul, Brazil. This species is of great sanitary importance, since it is capable of causing and transmitting various diseases, such as paralysis (OTRANTO et al., 2012), Rocky Mountain spotted fever (Rickettsia rickettsii (Wolbach, 1919)) (DEMMA et al., 2005; DEL FIOL et al.,

\footnotetext{
*Corresponding author: Kathleen Tavares Winkel

Departamento de Microbiologia e Parasitologia, Instituto de Biologia,

Universidade Federal de Pelotas - UFPEL, Campus Capáo do Leão, s/nº,

CEP 96010-900, Pelotas, RS, Brasil

e-mail: kathwinkel@gmail.com
}

2010), canine babesiosis (Babesia vogeli Reichenow, 1937), and ehrlichiosis (Donatien and Lestoquard, 1935) (NDIP et al., 2007). Dogs are the preferred hosts of $R$. sanguineus (EVANS et al., 2000); however, human beings may become accidental hosts. Consequently, the probability of infection by pathogens carried by this species in human beings is high, due to the increase in population density of ticks and the number of hosts, enforcing the need for monitoring.

This study aims to report the first occurrence of $R$. sanguineus sensu lato, both in Rattus norvegicus (Berkenhaut, 1769) and in Rattus rattus (Linnaeus, 1758) (Rodentia, Muridae), in the state of Rio Grande do Sul, Brazil. 
The rodents were captured weekly from two sites ( $31^{\circ} 46^{\prime} 49.8^{\prime \prime} \mathrm{S}$, $52^{\circ} 19^{\prime} 32.9^{\prime \prime} \mathrm{W}$ and $\left.31^{\circ} 46^{\prime} 51.8^{\prime} \mathrm{S}, 52^{\circ} 20^{\prime} 38.2^{\prime \prime} \mathrm{W}\right)$, in the port area located in the city of Pelotas, Rio Grande do Sul, Brazil, during the period from January to May 2013, using Tomahawk ${ }^{\oplus}$ traps $(29 \mathrm{~cm}$ $\times 18 \mathrm{~cm} \times 15 \mathrm{~cm}$ ). The ticks were collected directly from rodents, by means of brushing, and fixed in ethanol $70^{\circ} \mathrm{GL}$. Thereafter, the ticks were mounted on permanent slides in Hoyer's medium.

The identification of Rhipicephalus sanguineus larvae lacks specific bibliography; therefore we used the diagnostic characteristics of adult morphology, through the dichotomous keys of Walker et al. (2000) and Pratt and Stojanovich (1969). In order to confirm the identification, adults were collected, identified with the abovementioned keys and reared in the laboratory to obtain the larvae; then a morphological comparison was performed between the laboratory obtained larvae and the collected larvae.

The capture methods and euthanasia (CFMV, 2012) adopted for rodents went through a standardization process by the
Animal Experimentation and Ethics Commission (EAEC) of Universidade Federal de Pelotas, registered under the number 6615 and authorized by the Chico Mendes Institute for Biodiversity Conservation (ICMBio), under the number 35546-1. According to ICMBio, these species should be removed from the natural environment, because they are considered plagues and, therefore, require euthanasia.

Overall, we collected 35 Rattus norvegicus, 7 Rattus rattus and 9 Rhipicephalus sanguineus sensu lato larvae; this was the only tick species collected. From these, $6 R$. sanguineus sensu lato larvae in 2 male $R$. rattus individuals ( 5 in 1 of the hosts) and 3 larvae in 2 female $R$. norvegicus individuals. This tick species has already been found parasitizing $R$. norvegicus in the Distrito Federal, Brazil, but the author did not mention the tick's stage (YOSHIZAWA et al., 1996), and has also been found parasitizing an adult male in Chile (GONZÁLEZACUÑA et al., 2003).
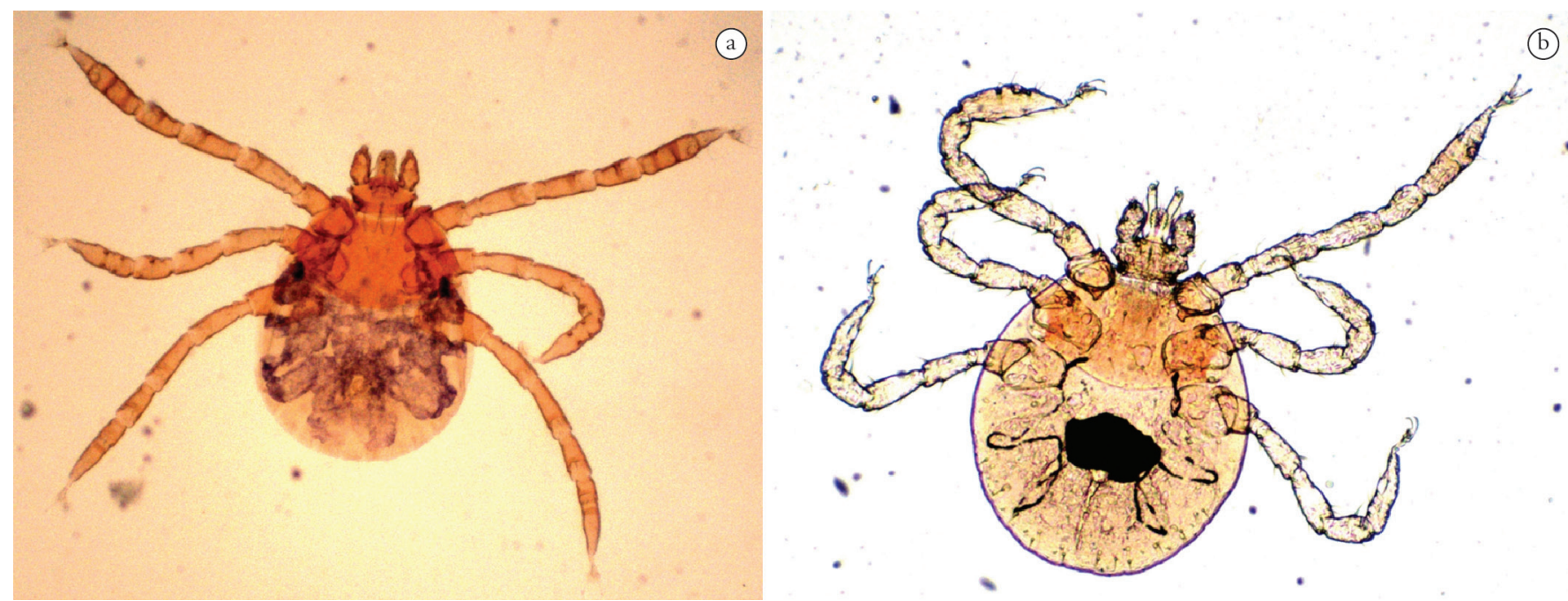

Figure 1. a)Rhipicephalus sanguineus latu sensu larvae found parasitizing Rattus rattus and Rattus norvegicus. b) Newly hatched Rhipicephalus sanguineus latu sensu larvae reared in laboratory.

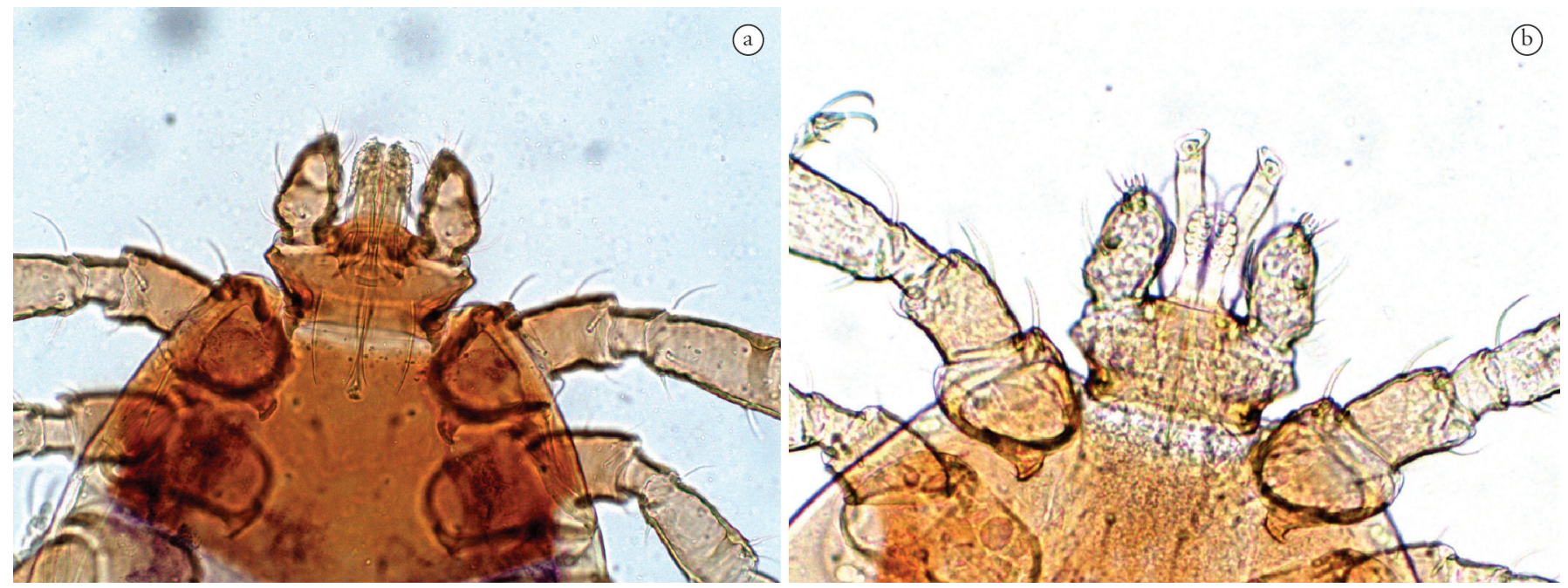

Figure 2. a)Capitulum of Rhipicephalus sanguineus latu sensu larvae found parasitizing Rattus rattus and Rattus norvegicus. b)Capitulum of Rhipicephalus sanguineus latu sensu larvae reared in laboratory. 
This is the first study regarding the occurrence of $R$. sanguineus sensu lato larvae in Rattus sp. and, since there is no description of larvae in the bibliography, some diagnostic characteristics of adults were analyzed, them being: the presence of festoons (Figures 1a, b), basis capituli of hexagonal shape and short hypostome (Figures $2 \mathrm{a}, \mathrm{b}$ ). In addition to these structures, the chaetotaxy is identical in both the larvae collected from rodents and the larvae obtained in the laboratory.

In the laboratory, $R$. sanguineus larvae presented a high susceptibility of infection with $R$. rickettsii (LABRUNA et al., 2008; PIRANDA et al., 2011). Furthermore, this species has also been naturally infected by rickettsiae, from the spotted fever group (ROZENTAL et al., 2002; MORAES-FILHO et al., 2009), with a high prevalence in the Brazilian Southeast region, constituting a disease which is difficult to diagnose (DEL FIOL et al., 2010), since the symptoms may be confused with other diseases and, if not treated early, it can lead to death (LEMOS et al., 2002). There are records of Rocky Mountain spotted fever, during the period from 2005 to 2009, in Cerro Largo, Rio Grande do Sul, Brazil (BRASIL, 2004), located approximately $560 \mathrm{~km}$ from Pelotas. Horses, dogs and human beings, seropositive for rickettsiae (from the spotted fever group), were found in the same city (SANGIONI et al., 2011).

Parasitism by $R$. sanguineus in human beings has been recorded in Brazil, and it can be caused both by immature and adult ticks (DANTAS-TORRES et al., 2006; SERRA-FREIRE, 2010). Studies have shown a predisposition to parasitize human beings when exposed to high temperatures (PAROLA et al., 2008), which may also be related to population growth and the availability of human hosts.

Thus, we conclude that it is relevant, from a public health perspective, to monitor both the population density of Rhipicephalus sanguineus sensu lato and the emergence and record in new hosts, as reported in this study. The record of synanthropic rodents of genus Rattus as hosts of this tick species becomes important, due to their high capacity for population growth within a short period of time, as well as to their interaction with other domestic animals living close to human beings.

In this context and given the incidence of this tick on dogs in this region, we intend to advance the studies by collecting $R$. sanguineus in urban dogs and rats to perform a molecular analysis of this tick on both hosts.

\section{Acknowledgements}

We thank Profa. Dr ${ }^{\mathrm{a}}$. Nara Amélia Farias for her assistance in the rearing of ticks in the laboratory.

\section{References}

Brasil. Ministério da Saúde. Febre Maculosa - Casos confirmados notificados no Sistema de Informação de Agravos de Notificação. Sinan Net [online]. 2004 [cited 2013 Out 5]. Available from: http:// dtr2004.saude.gov.br/sinanweb/tabnet/dh?sinannet/fmaculosa/bases/ febremaculosabrnet.def.
Conselho Federal de Medicina Veterinária - CFMV. Resolução nº1000 de 11 de Maio de 2012. Dispóe sobre procedimentos e métodos de eutanásia em animais e dá outras providências. Portal CFMV [online]. 2013 [cited 2013 Out 5]. Available from: http://www.cfmv. org.br/portal/legislacao_resolucoes.php.

Dantas-Torres F, Figueredo LA, Brandão-Filho SP. Rhipicephalus sanguineus (Acari: Ixodidae), the brown dog tick, parasitizing humans in Brazil. Rev Soc Bras Med Trop 2006; 39(1): 64-67. PMid:16501769. http://dx.doi.org/10.1590/S0037-86822006000100012

Del Fiol FS, Junqueira FM, Rocha MCP, Toledo MI, Barberato Filho S. A febre maculosa no Brasil. Rev Panam Salud Publica 2010; 27(6): 461466. http://dx.doi.org/10.1590/S1020-49892010000600008

Demma LJ, Traeger MS, Nicholson WL, Paddock CD, Blau DM, Eremeeva ME, et al. Rocky Mountain spotted fever from an unexpected tick vector in Arizona. N Engl J Med 2005; 353(6): 587-594. PMid:16093467. http://dx.doi.org/10.1056/NEJMoa050043

Evans DE, Martins JR, Guglielmone AA. A review of the ticks (Acari, Ixodida) of Brazil, their hosts and geographic distribution - 1. The state of Rio Grande do Sul, Southern Brazil. Mem Inst Oswaldo Cruz 2000; 95(4): 453-470. PMid:10904399. http://dx.doi. org/10.1590/S0074-02762000000400003

González-Acuña D, Venzal JM, Guglielmone AA. Primer registro de Rhipicephalus sanguineus (Latreille, 1806) (Acari: Ixodidae) en Rattus norvegicus (Mammalia: Rodentia) en Chile. Gayana 2003; 67(1): 120-121.

Labruna MB, Ogrzewalska M, Martins TF, Pinter A, Horta MC. Comparative susceptibility of larval stages of Amblyomma aureolatum, Amblyomma cajennense, and Rhipicephalus sanguineus to infection by Rickettsia rickettsii. J Med Entomol 2008; 45(6): 1156-1159. http:// dx.doi.org/10.1603/0022-2585(2008)45[1156:CSOLSO]2.0.CO;2

Lemos ERS, Rozental T, Villela CL. Brazilian spotted fever: description of a fatal clinical case in the State of Rio de Janeiro. Rev Soc Bras Med Trop 2002; 35(5): 523-525. PMid:12621675. http://dx.doi.org/10.1590/ S0037-86822002000500017

Moraes-Filho J, Pinter A, Pacheco RC, Gutmann TB, Barbosa SO, Gonzáles MA, et al. New epidemiological data on Brazilian spotted fever in an endemic area of the state of São Paulo, Brazil. Vector Borne Zoonotic Dis 2009; 9(1): 73-78. PMid:18847319. http://dx.doi.org/10.1089/ vbz.2007.0227

Ndip LM, Ndip RN, Ndive VE, Awuh JA, Walker DH, McBride JW. Ehrlichia species in Rhipicephalus sanguineus ticks in Cameroon. Vector Borne Zoonotic Dis 2007; 7(2): 221-227. PMid:17627442. http://dx.doi. org/10.1089/vbz.2006.0608

Otranto D, Dantas-Torres F, Tarallo VD, Ramos RA, Stanneck D, Baneth G, et al. Apparent tick paralysis by Rhipicephalus sanguineus (Acari: Ixodidae) in dogs. Vet Parasitol 2012; 188(3-4): 325-329. PMid:22546547. http://dx.doi.org/10.1016/j.vetpar.2012.04.005

Parola P, Socolovschi C, Jeanjean L, Bitam I, Fournier PE, Sotto $A$, et al. Warmer weather linked to tick attack and emergence of severe rickettsioses. PLoS Negl Trop Dis 2008; 2(11): e338. PMid:19015724 PMCid:PMC2581602. http://dx.doi.org/10.1371/ journal.pntd.0000338

Piranda EM, Faccini JL, Pinter A, Pacheco RC, Cançado PH, Labruna MB. Experimental infection of Rhipicephalus sanguineus ticks with the bacterium Rickettsia rickettsii, using experimentally infected dogs. Vector Borne Zoonotic Dis 2011; 11(1): 29-36. PMid:20569011. http://dx.doi. org/10.1089/vbz.2009.0250 
Pratt HD, Stojanovich CJ. Acarina: Illustrated key to some common adult female mites and adult ticks. In: Centers for Disease Control and Prevention. CDC Pictorial keys: Arthropods, reptiles, birds and mammals of public health significance. Department of Health, Education and Welfare, Public Health Service, Communicable Disease Center; 1969. p. 26-37.

Rozental T, Bustamante MC, Amorin M, Serra-Freire NM, Lemos ERS. Evidence of spotted fever group Rickettsiae in state of Rio de Janeiro, Brazil. Rev Inst Med Trop S Paulo 2002; 44(3): 155-158. PMid:12163909. http://dx.doi.org/10.1590/S0036-46652002000300008

Sangioni LA, Vogel FFS, Cadore GC, Hilger RB, Tonim R, Pacheco RC, et al. Rickettsial infection in Cerro Largo, State of Rio Grande do
Sul, Brazil. Arq Bras Med Vet Zootec 2011; 63(2): 511-514. http://dx.doi. org/10.1590/S0102-09352011000200035

Serra-Freire NM. Occurrence of ticks (Acari: Ixodidae) on human hosts, in three municipalities in the State of Pará, Brazil. Rev Bras Parasitol Vet 2010; 19(3): 141-147. PMid:20943016. http://dx.doi.org/10.1590/ S1984-29612010000300003

Walker JB, Keirans JE, Horak IG. The genus Rhipicephalus (Acari: Ixodidae). A guide to the Brown ticks of the world. London: Cambridge University Press; 2000. p. 643. http://dx.doi.org/10.1017/CBO9780511661754

Yoshizawa MAC, Souza JL, Bredt A, Baggio D. Ectoparasitos de Rattus norvegicus no Distrito Federal, Brasil. Rev Bras Parasitol Vet 1996; 5(1): 39-42. 